\title{
Interpreting the Flexibilities Under the TRIPS Agreement
}

\author{
Carlos M. Correa
}

\begin{abstract}
While the TRIPS Agreement provides for minimum standards of protection of intellectual property, it leaves certain degree of policy space for WTO members, whether developed or developing countries, to implement the Agreement's provisions in different manners, to legislate in areas not subject to the minimum standards under the Agreement, and to develop legal interpretations of such provisions to determine the scope and content of the applicable obligations. This paper focuses on some aspects of how panels and the Appellate Body of the WTO have interpreted said provisions. The paper also draws general conclusions for the implementation of TRIPS flexibilities, which are of crucial importance for the design of a pro-competitive intellectual property system and, in particular, for achieving public health objectives, as specifically recognized by the Doha Declaration on TRIPS and Public Health.
\end{abstract}

\section{Introduction}

While the Agreement on Trade-Related Aspects of Intellectual Property Rights ('the TRIPS Agreement') has had a major impact in framing national laws on intellectual property rights (IPRs) - notably in developing countries - and has led to some degree of harmonization of such laws, it is not a uniform law on IPRs.

One the one hand, the TRIPS Agreement provides for minimum standards, thereby allowing the members of the World Trade Organization (WTO) to adopt broader protections. ${ }^{1}$ Many such 'TRIPS-plus' protections have been established through free trade agreements signed by the US and the European Union with

\footnotetext{
${ }^{1}$ Article 1.1 of the TRIPS Agreement makes it clear, however, that no WTO member is obliged to grant such a broader protection. See, e.g., Correa (2020b), p. 21.
}

C. M. Correa $(\bowtie)$

South Centre, Geneva, Switzerland

e-mail: director@southcentre.int 
developing country partners. ${ }^{2}$ Examples of such TRIPS-plus protections include (in the area of patents) the extension of the patent term in order to compensate for delays in the grant of a patent or the marketing approval of a pharmaceutical product, ${ }^{3}$ data exclusivity, ${ }^{4}$ and what is known as 'patent linkage', ${ }^{5}$ among others.

On the other hand, the TRIPS Agreement leaves some room for WTO members, whether developed or developing countries, to implement the Agreement's provisions in different manners, to legislate in areas not subject to the minimum standards under the Agreement, and to develop legal interpretations of such provisions to determine the scope and content of the applicable obligations.

The possibility, and admissibility, of differences in the implementation of the provisions of the TRIPS Agreement are expressly recognized in Article 1.1 of the Agreement: "Members shall be free to determine the appropriate method of implementing the provisions of this Agreement within their own legal system and practice." Competition law, which may be applied to control the acquisition or exercise of IPRs, is an example of the second situation in which the Agreement does not provide a binding standard. ${ }^{6}$ The room for different interpretations may result from the absence of definitions. One example is the lack of a definition of the concept of 'invention,' which differs among countries and allows WTO members not to grant patents, for instance, on developments without a technical effect (such as under European law), or to grant or not grant patents on genetic materials. ${ }^{7}$ In many cases, the space for different interpretations derives from general expressions or ambiguities in the text resulting from compromises reached in the negotiation of the Agreement. An outstanding example is the WTO members' right to grant compulsory licenses due to lack of working of a patent, an issue indirectly referred to in Article 27.1 of said Agreement. ${ }^{8}$ The task of the interpreter is particularly daunting when the text includes general terms such as "reasonably," "unreasonably,", "unjustifiable,", or "unjustifiably."11

The actual policy space available under the TRIPS Agreement-beyond those areas not covered under the Agreement-depends, in the last instance, on the

\footnotetext{
${ }^{2}$ See, e.g., Morin and Surbeck (2020).

${ }^{3}$ See, e.g., The Law Library of Congress, Global Legal Research Center (2016). Available from: https://www.loc.gov/law/help/patent-terms/patent-term-extensions-adjustments.pdf.

${ }^{4}$ Shaikh (2016).

${ }^{5}$ Son et al. (2018). Available from: https://doi.org/10.1186/s12992-018-0423-0.

${ }^{6}$ UNDP (2015b). Available from: https://www.undp.org/content/undp/en/home/librarypage/hivaids/using-competition-law-to-promote-access-to-medicine.html.

${ }^{7}$ Minn (2016).

${ }^{8}$ Article 27.1 in fine: “. . . patents shall be available and patent rights enjoyable without discrimination as to the place of invention, the field of technology and whether products are imported or locally produced." See, e.g., Correa (2005). See also below.

${ }^{9} \mathrm{~A}$ large number of provisions in the TRIPS Agreement uses these terms, e.g., Articles 8.2, 13, 15.5, 25.5, 26.2, 30. 31(b), 31(1), 34.2, 37, 1, 39.2(c), 41, 43.

${ }^{10}$ Article 4(d) of the TRIPS Agreement.

${ }^{11}$ Article 20 of the TRIPS Agreement.
} 
interpretation of the Agreement's provisions. This paper focuses on some aspects of how panels and the Appellate Body of the WTO have interpreted said provisions. It discusses, first, the concept of 'TRIPS flexibilities' and the possible types of such flexibilities as found in the legislation of developing and developed countries. Second, the paper discusses the references to such flexibilities in WTO jurisprudence. Third, it briefly refers to some of the principles of interpretation that are relevant for the use of TRIPS flexibilities, including the value of dispute settlement rulings, the search for the ordinary meaning of the terms used, the context, and the object and purpose of the treaty. Fourth, it discusses the legal status of the Doha Declaration on the TRIPS Agreement and Public Health adopted at the 4th WTO Ministerial Conference in November 2001. ${ }^{12}$ There is no attempt in this paper to analyze the specific content of the rulings in TRIPS-related disputes; however, the paper does draw some general conclusions for the implementation of such flexibilities, which are of crucial importance for the design of a pro-competitive intellectual property system and, in particular, for achieving public health objectives (as specifically recognized by the Doha Declaration). ${ }^{13}$

\section{Defining the TRIPS Flexibilities}

The terminology used to refer to the policy space available for the implementation of the TRIPS Agreement has evolved. Expressions such as "room to maneuver," "margins of freedom," "safeguards," and "margin of discretion" were used in the early studies and reports that identified various aspects of such space. ${ }^{14}$ Currently, the diversity of legislative options available under said Agreement is generally known as 'TRIPS flexibilities.'

The term 'flexibility' appears in the Preamble (sixth paragraph) and in Article 66.1 of the TRIPS Agreement but it is used there with a broader meaning. It indicates that least-developed countries (LDCs) are not bound to comply with the TRIPS Agreement obligations (except Articles 3 through 5) during the transition period:

In view of the special needs and requirements of least-developed country Members, their economic, financial and administrative constraints, and their need for flexibility to create a viable technological base, such Members shall not be required to apply the provisions of this Agreement, other than Articles 3, 4 and 5, for a period of ... ${ }^{15}$

\footnotetext{
${ }^{12}$ Available from: https://www.who.int/medicines/areas/policy/tripshealth.pdf?ua=1. Hereinafter, "the Doha Declaration."

${ }^{13}$ See, e.g., Velásquez et al. (2020). https://www.southcentre.int/book-by-the-south-centre-2020/ \#more-14014.

${ }^{14}$ Germán Velásquez (2013), p. 5. https://www.southcentre.int/wp-content/uploads/2013/05/ RP47_WTO-role-in-IP-and-access-to-medicines_EN.pdf.

${ }^{15}$ Emphasis added.
} 
The terminology 'TRIPS flexibilities' does include the exemption for LDCs, but it also encompasses possible variations in the manner in which the TRIPS Agreement's provisions are interpreted and implemented as they are applied to countries actually subject to them. Such terminology was used for the first time with this latter meaning in the context of the WTO in paragraph 4 of the Doha Declaration. ${ }^{16}$ Said paragraph states:

4. We agree that the TRIPS Agreement does not and should not prevent Members from taking measures to protect public health. Accordingly, while reiterating our commitment to the TRIPS Agreement, we affirm that the Agreement can and should be interpreted and implemented in a manner supportive of WTO Members' right to protect public health and, in particular, to promote access to medicines for all. In this connection, we reaffirm the right of WTO Members to use, to the full, the provisions in the TRIPS Agreement, which provide flexibility for this purpose. ${ }^{17}$

The Declaration confirmed the availability of a number of flexibilities. Its adoption was a response to the concerns of developing countries about the obstacles they faced when seeking to implement measures to promote access to affordable medicines, without limitation to certain diseases, in the interest of public health. ${ }^{18}$

Since the adoption of the Doha Declaration, the concept of 'TRIPS flexibilities' has been referenced in a vast body of literature, especially (but not only) in relation to access to medicines, ${ }^{19}$ and in numerous resolutions of $\mathrm{UN}$ agencies ${ }^{20}$ and bodies, including the World Health Organization (WHO), the Human Right Council (HRC), ${ }^{21}$ and the UN Assembly, as well as in reports of the UN Special Rapporteur

\footnotetext{
${ }^{16}$ Paragraph 17 of the general Doha Ministerial Declaration states: "We stress the importance we attach to implementation and interpretation of the Agreement on Trade-Related Aspects of Intellectual Property Rights (TRIPS Agreement) in a manner supportive of public health, by promoting both access to existing medicines and research and development into new medicines and, in this connection, are adopting a separate Declaration." https://www.wto.org/english/thewto_e/minist_e/ min01_e/mindecl_e.htm.

${ }^{17}$ Emphasis added.

${ }^{18}$ The Council for TRIPS convened special sessions (which were held in June, August, and September of 2001) to deal with the relationship between health and TRIPS. See, e.g., the submissions made by the European Communities and their Members States on the relationship between the provisions of the TRIPS Agreement and access to medicines, IP/C/W/280 (12 June 2001); and submissions by the African Group, Barbados, Bolivia, Brazil, Cuba, Dominican Republic, Ecuador, Honduras, India, Indonesia, Jamaica, Pakistan, Paraguay, Philippines, Peru, Sri Lanka, Thailand, and Venezuela on TRIPS and public health, IP/C/W/296 (29 June 2001). See also Council for TRIPS Special Discussion on Intellectual Property and Access to Medicines, IP/C/M/31 (10 July 2001).

${ }^{19}$ See, e.g., Velásquez et al. (2020). https://www.southcentre.int/book-by-the-south-centre-2020/ \#more-14014.

${ }^{20}$ One of the first studies on TRIPS flexibilities was published by the UNCTAD (1996). https:// unctad.org/en/docs/ite1_en.pdf.

${ }^{21}$ On the relationship between the TRIPS Agreement and the human right to health, see, e.g., Sellin (2015). https://link.springer.com/article/10.1007/s40802-015-0047-5\#Abs1.
} 
on the Right to Health. ${ }^{22}$ For instance, the World Health Assembly (WHA) urged member states "to consider, whenever necessary, adapting national legislation in order to use to the full the flexibilities contained in the Agreement on Trade-Related Aspects of Intellectual Property Rights (TRIPS)". ${ }^{23}$ The Global Strategy and Plan of Action on Public Health, Innovation and Intellectual Property ${ }^{24}$ explicitly referred to the flexibilities reaffirmed by the Doha Declaration, including the research exception (Element 2.4e), the transitional period for least-developed countries (LDCs) (Element 6.1b), and the regulatory exception or "Bolar exception" (Element 6.3a). A 2011 resolution adopted by the HRC, and subsequent resolutions on the matter, also noted the governments' right to use, to the fullest extent, the provisions of the TRIPS Agreement, the Doha Declaration, and the WTO General Council Decision of 30 August 2003 in the context of the HIV/AIDS epidemic. ${ }^{25}$ Importantly, Goal 3. Target 3.b of the Sustainable Development Goals (SDGs), as adopted by the UN General Assembly, also refers to the TRIPS flexibilities:

Goal 3. Target 3.b: Support the research and development of vaccines and medicines for the communicable and noncommunicable diseases that primarily affect developing countries, provide access to affordable essential medicines and vaccines, in accordance with the Doha Declaration on the TRIPS Agreement and Public Health, which affirms the right of developing countries to use to the full the provisions in the Agreement on Trade-Related Aspects of Intellectual Property Rights regarding flexibilities to protect public health, and, in particular, provide access to medicines for all. ${ }^{26}$

There is no agreed-upon definition of 'TRIPS flexibilities.' In accordance with a WIPO document, the term "flexibilities" means that there are "different options through which TRIPS obligations can be transposed into national law so that national interests are accommodated and yet TRIPS provisions and principles are complied with." 27 That concept implies that the legislative options made are compatible with the TRIPS Agreement and, hence, fully legitimate. Although this remark may be deemed trite, it is important to make it in view of the reluctance of some developed countries to accept the use of such flexibilities, and even to exert pressures on or apply retaliatory trade sanctions against countries that do comply with the Agreement's obligations. This position is well reflected in the continuous

\footnotetext{
${ }^{22}$ See, e.g., WHO, WIPO, and WTO (2012). https://www.wipo.int/edocs/pubdocs/en/global_ challenges/628/wipo_pub_628.pdf.

${ }^{23}$ WHA 56.27, "Intellectual property rights, innovation and public health" (28 May 2003). Available from: https://apps.who.int/gb/archive/pdf_files/WHA56/ea56r27.pdf?ua=1. For a list of WHO resolutions referring to intellectual property, see Germán Velásquez, Carlos M. Correa, and Vitor Ido, op. cit., pp. 73-75.

${ }^{24}$ Available from: https://www.who.int/phi/implementation/phi_globstat_action/en/. See, Germán Velásquez (2019).

${ }^{25} \mathrm{See}$, https://www.ohchr.org/EN/Issues/HIV/Pages/Documents.aspx.

${ }^{26}$ Resolution adopted by the General Assembly on 25 September United Nations General Assembly (2015), A/RES/70/1. https://www.un.org/ga/search/view_doc.asp?symbol=A/RES/70/1\& Lang $=\mathrm{E}$.

${ }^{27}$ WIPO (2010), p. 11. https://www.wipo.int/meetings/en/doc_details.jsp?doc_id=142068.
} 
use by the US of the Special Section 301 of the US Trade Act $1974,{ }^{28}$ and in the European Commission Staff Working Document on the protection and enforcement of intellectual property rights in third countries. ${ }^{29}$

There are different types of TRIPS flexibilities. Some refer to the scope and extent of the substantive rights to be recognized under the Agreement, ${ }^{30}$ and others to the ways in which such rights can be enforced. One way of grouping flexibilities is also to take into account "the point in time at which Members may resort to them: (i) in the process of the acquisition of the right; (ii) defining the scope of the right; and (iii) when enforcing the right." 31 As noted in one report, those flexibilities

... sometimes are made very explicit (as in the right of each WTO Member to choose its national regime of exhaustion of IP rights, hence allowing parallel imports), and in other instances follow from the use of general and open terms in TRIPS provisions (such as legitimate interests, justifiability, ordre public and morality) that WTO Member can - within the limits of accepted principles of treaty interpretation in public international law - interpret and implement in accordance with their public policy preferences. ${ }^{32}$

Given the possible variations in national regimes in interpreting and implementing the TRIPS Agreement, it would be an impossible task to identify all flexibilities. They can be found in all the areas covered by the Agreement, and they can be identified as new circumstances arise. Thus, the exception to copyright protection, which is of particular importance to ensure access to knowledge and preserve a robust public domain, ${ }^{33}$ needs to be considered in light of technological developments. ${ }^{34}$ WIPO's Database on Flexibilities in the Intellectual Property System $^{35}$ provides information on just fourteen TRIPS flexibilities as provided for in the national laws of some countries, but the list is certainly much longer and their use in national laws and regulations more extensive. As noted, the type and use of such flexibilities have been widely explored, most particularly in relation to public health policies and access to medicines, ${ }^{36}$ in academic literature, numerous reports, and

\footnotetext{
${ }^{28}$ See, e.g., Correa (2020a).

${ }^{29}$ European Commission (2020). https://trade.ec.europa.eu/doclib/docs/2020/january/tradoc 158561.pdf.

${ }^{30}$ The 'scope' of a right delimits the boundaries and defines its content; the 'extent' refers to the legal limitations on the exercise of the right.

${ }^{31}$ WIPO (2010), op. cit., p. 12.

${ }^{32}$ Ruse-Khan and Puutio (2017), p. 10. Available from: https://www.unescap.org/sites/default/files/ IPR\%20Handbook.pdf.

${ }^{33}$ See, e.g., Geiger et al. (2013). https://digitalcommons.wcl.american.edu/cgi/viewcontent.cgi? article $=1041 \&$ context $=$ research.

${ }^{34}$ Eger and Scheufen (2012). https://www.researchgate.net/publication/280043122_The_past_and_ the_future_of_copyright_law_technological_change_and_beyond.

${ }^{35}$ Available from: https://www.wipo.int/ip-development/en/agenda/flexibilities/database.html.

${ }^{36}$ See, e.g., Germán Velásquez, Carlos M. Correa, and Vitor Ido, op. cit.
} 
other sources of information. ${ }^{37}$ Box 1 includes references to some of the flexibilities available in the field of public health.

\section{Box 1 Public health-related TRIPS flexibilities}

(1) Flexibility in the choice of patentability criteria, including for chemical entities and biologics - WTO members have considerable policy space to define what an 'invention' is and to apply rigorous standards of patentability to avoid the grant of patents that, without making a genuine technical contribution, may distort market competition.

(2) Compulsory license-Widely recognized in the legislation of developed and developing countries - and granted since the adoption of the TRIPS Agreement by administrations or courts in countries such as Thailand, Ecuador, Indonesia, India, USA, Italy, and Germany-compulsory licenses may be necessary to correct market distortions (abuses of market power, unfair pricing, refusal to license, etc.).

(3) Government use - In many cases governments may decide, consistently with the TRIPS Agreement, to use patented inventions for non-commercial purposes, such as for ensuring the supply of essential medicines.

(4) Compulsory licenses for the supply of medicines to countries with a lack of or insufficient manufacturing capacity - Compulsory licenses exclusively for the export of medicines can be granted under the amendment introduced to the TRIPS Agreement in 2017 and the waiver adopted by WTO in 2003.

(5) Test data protection-The TRIPS Agreement (Article 39.3) requires WTO members to protect test data against unfair competition, which does not create exclusive rights. The Agreement is complied with if legislation on unfair competition is implemented to protect such data.

(6) Exemptions) for $\mathbf{L D C s}$ - LDCs need not grant patents for pharmaceuticals and test data protection at least until 2033 under the extended transition period provided for under Article 66.1 of the TRIPS Agreement.

(7) Parallel importation-Importing protected medicines from any country where they can be purchased cheaper than locally is consistent with the TRIPS Agreement.

(8) Pre and post patent grant opposition-Procedures before patent offices provide for the possibility for third parties to contribute to the

(continued)

\footnotetext{
${ }^{37}$ See, e.g., Medicines Law \& Policy, The TRIPS Flexibilities Database. Available from: http:// tripsflexibilities.medicineslawandpolicy.org/. See also, The Graduate Institute Geneva, Knowledge Portal on Innovation and Access to Medicines. https://www.knowledgeportalia.org/.
} 
Box 1 (continued)

examination process through 'observations' or 'oppositions,' whether before or after the grant of a patent, or both.

(9) Use of competition law to address the misuse of IPRs-Competition law may be applied to correct market distortions created through the abuse of IPRs.

(10) Bolar exception-'Bolar exceptions' are important to accelerate the entry of generic products and promote a dynamic market for medicines.

(11) Research or experimentation exception-This exception allows research to be conducted by third parties on patented inventions, for instance, to improve on them or derive new inventions.

(12) Disclosure requirement, particularly for biologics-The full and precise disclosure of an invention is crucial for the patent system to perform its informational function. This is particularly relevant for biologicals, which cannot be described in the same way as medicines produced by chemical synthesis

(13) Flexibilities in enforcement of IP-Measures to enforce IPRs-such as reversal of the burden of proof, determination of infringement by equivalence and damages, and border measures - if overly broad, may distort competition by discouraging or preventing market entry and the availability of generic medicines. Provisional injunctions need to be cautiously granted so as not to distort the market dynamics, generally after giving the alleged infringer an opportunity to articulate his defense. Permanent injunctions may be denied for public health reasons under certain circumstances.

(14) Security exception-Compliance with obligations under the TRIPS Agreement can be suspended, inter alia, in cases of emergency in international relations, such as in the case of a pandemic (Article 73 (b) of the Agreement).

Source: adapted from South Centre, "A Public Health Approach to Intellectual Property Rights: Public Health Related Flexibilities in the TRIPS Agreement," available from: https://ipaccessmeds.southcentre.int/wp-con tent/uploads/2018/12/Public-Health-Related-Flexibilities-in-the-TRIPSAgreement.pdf.

Any WTO member can make use of the TRIPS flexibilities, as applicable, in order to attain public health or other public objectives and, in fact, both developed and developing countries have done so. Thus, the flexibility in the TRIPS Agreement permitted the US to maintain a double-novelty standard depending on whether the disclosure of the invention had taken place within or outside the territory of the US 
(35 USC section 102 (a)). ${ }^{38}$ In defending this flexibility, which has allowed for the misappropriation of genetic resources and traditional knowledge, ${ }^{39}$ the US held that in the TRIPS Agreement there was "no prescription as to how WTO Members define what inventions are to be considered 'new' within their domestic systems" and, hence, that its legislation was "perfectly consistent with the provisions of the TRIPS Agreement." Another example in the US is the doctrine that allows US courts not to grant a permanent injunction despite the proven existence of an infringement of IPRs, in accordance with the precedent set by the US Supreme Court in the eBay vs. MercExchange case. ${ }^{41}$ There are also many examples in Europe ${ }^{42}$ where, for instance, the European Parliament's Resolution of 2 March 2017 on EU options for improving access to medicines (2016/2057(INI)) emphasized "that the European Patent Office (EPO) and the Member States should only grant patents on medicinal products that strictly fulfil the patentability requirements of novelty, inventive step and industrial applicability, as enshrined in the European Patent Convention" (paragraph 48). ${ }^{43}$ More recent examples are the amendments to the patent laws in Canada and Germany to address the COVID-19 emergency. Bill C 132020 of Canada, ${ }^{44}$ for instance, added a new section to the Patent Act implementing a new type of compulsory license for patents:

19.4 (1) The Commissioner shall, on the application of the Minister of Health, authorize the Government of Canada and any person specified in the application to make, construct, use and sell a patented invention to the extent necessary to respond to the public health emergency described in the application.

\footnotetext{
${ }^{38}$ According to this section, "[a] person shall be entitled to a patent unless the invention was known or used by others in this country, or patented or described in a printed publication in this or a foreign country, before the invention thereof by the applicant for patent, or the invention was patented or described in a printed publication in this or a foreign country or in public use or on sale in this country, more than one year prior to the date of the application for patent in the United States." This rule was amended by the Leahy-Smith America Invents Act (2011). http://www.wipo.int/edocs/ lexdocs/laws/en/us/us219en.pdf.

${ }^{39}$ Reid (2019). https://digitalcommons.law.ou.edu/cgi/viewcontent.cgi?article $=1121 \&$ context $=$ ailr.

${ }^{40}$ See, Document IP/Q3/USA/1 (1 May 1998). As a result of the relative novelty requirement of the US, several patents were granted to researchers or firms relating to or consisting of genetic materials or traditional knowledge acquired in developing countries. See, e.g., Mgbeoji (2006). https://books. google.fr/books? $\mathrm{id}=\mathrm{q} 4 \mathrm{MIoBKy} 88 \mathrm{MC} \& \mathrm{pg}=\mathrm{PA} 121 \& \mathrm{lpg}=\mathrm{PA} 121 \& \mathrm{dq}=$ biopiracy + us + patents $\&$ source $=$ bl\&ots $=-Z B M O h X L L n \&$ sig $=$ ACfU3U0DslCI-lxiwQuSmN-jeuuC-fafLQ\&hl=en \& $\mathrm{sa}=\mathrm{X} \& \mathrm{ved}=2 \mathrm{ahUKEwitsrmu} 8 \mathrm{~N} \_p A h U S x 4 U K H e 1 \_D H Y Q 6 A E w E n o E C A k Q A Q \# v=$ onepage $\&$ $\mathrm{q}=$ biopiracy $\% 20 \mathrm{us} \% 20$ patents $\& \mathrm{f}=$ false.

${ }^{41}$ eBay Inc. v. MercExchange, L.L.C., 547 U.S. 388 (2006), https://www.supremecourt.gov/ opinions/05pdf/05-130.pdf.

${ }^{42}$ For the use of TRIPS flexibilities in relation to plant patents, see, e.g., Correa (2014). https:// www.southcentre.int/wp-content/uploads/2014/11/RP55_Patent-Protection-for-Plants_EN.pdf.

See also, Prifti (2015).

${ }^{43}$ Available from: https://www.europarl.europa.eu/doceo/document/TA-8-2017-0061_EN.html.

${ }^{44}$ Available from: https://www.parl.ca/DocumentViewer/en/43-1/bill/C-13/royal-assent.
} 
In Germany, an amendment to the Patent Act provided that an invention relating to medicinal products, including narcotics; the active ingredients, starting materials, and auxiliary materials for these products; medical devices; laboratory diagnostics; aids; personal protective equipment; and products for disinfection of the products shall be used in the interest of public welfare ("öffentliche Wohlfahrt") or in the interest of the security of the Federation. ${ }^{45}$

\section{TRIPS Flexibilities in WTO Jurisprudence}

Despite the TRIPS Agreement being one of the most controversial components of the WTO system, and that it has given rise to a large number of proceedings under the Dispute Settlement Understanding, a relatively small number of cases has reached the phase of a panel or Appellate Body intervention.

Paradoxically, although the adoption of the TRIPS Agreement essentially was aimed at disciplining developing countries, who have been forced to make massive legislative changes to adapt to the Agreement's high minimum standards, ${ }^{46}$ most disputes leading to the establishment of a panel have been against developed countries (two against the US, ${ }^{47}$ two against the European Communities and their Member States, ${ }^{48}$ two against Canada, ${ }^{49}$ and one against Australia ${ }^{50}$ ). Only two developing countries were subject to such procedures: ${ }^{51}$ India (two complaints

\footnotetext{
${ }^{45}$ Fuchs (2020). https://www.twobirds.com/en/news/articles/2020/germany/covid-19-new-germanlegislation-to-fight-pandemic-may-affect-granted-patents.

${ }^{46}$ See, e.g., Correa (2011a).

${ }^{47}$ See, DS 160 Panel Report United States - Section 110(5) of US Copyright Act (2010); Appellate Body report DS 176 United States - Section 211 Omnibus Appropriations Act of 1998 (2002).

${ }^{48}$ See, DS 174 Panel Report European Communities - Protection of Trademarks and Geographical Indications for Agricultural Products and Foodstuffs (2005); DS 290 Panel Report, European Communities - Protection of Trademarks and Geographical Indications for Agricultural Products and Foodstuffs (2005).

${ }^{49}$ See, Report of the WTO Panel, Canada-Patent Protection for Pharmaceutical Products, WT/DS114/R; Report of the Appellate Body, Canada-Term of Patent Protection, WT/DS170/ $\mathrm{AB} / \mathrm{R}(2000)$.

${ }^{50}$ See Panel Report in DS435, 441, 458, 467, Australia - Certain Measures Concerning Trademarks, Geographical Indications and Other Plain Packaging Requirements Applicable to Tobacco Products and Packaging (2018) (hereinafter, "Australia-Tobacco Plain Packaging"). The panel report was appealed by Honduras and the Dominican Republic (see, https://www.wto.org/english/ tratop_e/dispu_e/cases_e/ds441_e.htm). The report of the Appellate Body was issued on June 9, 2020 (WT/DS435/AB/R WT/DS441/AB/R). On the situation of the Appellate Body as a result of the US blockade to the appointment of new members, see, e.g., Danish and Aileen Kwa (2019). Available from: https://www.southcentre.int/wp-content/uploads/2019/12/PB69_Crisis-at-theWTO $\% 2 \% 80 \% 99$ s-Appellate-Body-AB-Why-the-AB-is-Important-for-Developing-Members_ EN-1.pdf.

${ }^{51}$ A violation to the TRIPS Agreement was incidentally invoked in the Indonesia-Autos case in relation to the protection of trademarks. The panel, however, found that the United States had not
} 
concerning the implementation of Article 70.8, the so called "mailbox" provision) $)^{52}$ and China (criminal sanctions for copyright infringement and other issues). ${ }^{53}$ Only four developing countries (Indonesia, Cuba, Honduras, and the Dominican Republic) have been complaining parties (against Australia in the tobacco plain packaging case) in WTO disputes under the TRIPS Agreement that have reached such stage. ${ }^{54}$

In other cases of disputes initiated against developing countries, no panel was established. One example was a complaint by the US against Argentina on patents and test data protection. ${ }^{55}$ A mutually agreed-upon solution was communicated to the Dispute Settlement Body (DSB) on 20 June 2002. However, the parties did not reach a common understanding on the interpretation of Article 39.3 of the TRIPS Agreement, nor on the application of Article 70.7. ${ }^{56}$ Argentina has not to date introduced the data exclusivity regime that the US claimed would remedy the (unproven) violation of Article 39.3. Another example, further discussed below, was the US challenge in January 2001 against Brazilian legislation that authorizes the granting of compulsory licenses and parallel imports in instances when patents are not worked. ${ }^{57}$ The dispute ended several months later when the US complaint was withdrawn. ${ }^{58}$

The panel and Appellate Body reports produced in relation to the disputes mentioned above have, in practice, addressed the policy space available under the TRIPS Agreement, but they have only occasionally referred to the concept of 'flexibilities.' In China-Intellectual Property Rights, for instance, third parties

demonstrated that Indonesia was in breach of its TRIPS obligations (Report of the WTO Panel, Indonesia-Certain Measures Affecting The Automobile Industry, WT/DS 54/R, WT/DS 55/R, WT/DS 59/R, WT/DS 64/R (1998), para. 11.1-11.43).

${ }^{52}$ See Report of the Appellate Body, India-Patent Protection for Pharmaceutical and Agricultural Chemical Products, WT/DS50/AB/R (1998) and Report of the WTO Panel, India-Patent Protection for Pharmaceutical and Agricultural Chemical Products, WT/DS79/R (1998) (hereinafter, "India-Patents (US)").

${ }^{53}$ See Panel Report in IDS362, China-Measures Affecting the Protection and Enforcement of Intellectual Property Rights (2009) (hereinafter, "China-Intellectual Property Rights").

${ }^{54}$ Brazil requested the US consultations with regard to provisions of US legislation that limits the right to use or sell any federally-owned invention only to a licensee that agrees that any products embodying the invention or produced through the use of the invention will be manufactured substantially in the United States. See, United States-US Patents Code, WT/DS224/1 (7 February 2001). In DS 408, India complained about border measures imposed on the transit of medicines. See, European Union and a Member State-Seizure of Generic Drugs in Transit (2010). These cases were not ultimately pursued.

${ }^{55}$ Argentina-Patent Protection for Pharmaceuticals and Test Data Protection for Agricultural Chemicals, WT/DS171 (6 May 1999) and Argentina-Certain Measures on the Protection of Patents and Test Data, WT/DS196 (30 May 2000).

${ }^{56}$ See, Notification of Mutually Agreed Solution According to the Conditions Set Forth in the Agreement (IP/D/18/Add.1, IP/D/22/Add.1).

${ }^{57}$ See, Brazil-Measures Affecting Patent Protection, Request for the Establishment of a Panel by the United States, WT/DS199/3 (9 January 2001).

${ }^{58}$ Brazil-Measures Affecting Patent Protection, Notification of Mutually Agreed Solution, WT/DS199/4, G/L/454, IP/D/23/Add.1 (19 July 2001). 
alluded to the 'flexibility' allowed by the TRIPS Agreement in relation to the definition of 'commercial scale. ${ }^{59}$ The US noted, with respect to Article 1.1 of the Agreement, that the provision "only offers flexibility in how a Member implements TRIPS obligations and does not exempt a Member from full compliance with TRIPS obligations. ${ }^{\circ 0}$ In this case the panel confirmed that the TRIPS Agreement does not mandate specific forms of legislation. ${ }^{61}$ In relation to the US claim that China did not comply with Article 61 of the TRIPS Agreement, it stated:

The Panel may not simply assume that a Member must give its authorities wide discretion to determine what is on a commercial scale in any given case, and may not simply assume that thresholds, including numerical tests, are inconsistent with the relative benchmark in the first sentence of Article 61 of the TRIPS Agreement. As long as a Member in fact provides for criminal procedures and penalties to be applied in cases of wilful trademark counterfeiting or copyright piracy on a commercial scale, it will comply with this obligation. If it is alleged that a Member's method of implementation does not so provide in such cases, that allegation must be proven with evidence...(para. 7.602).

A few references to the 'flexibilities' allowed by the prohibition contained in Article 20 of the TRIPS Agreement can be found in the panel report in AustraliaTobacco Plain Packaging. For instance, the panel stated:

On their face, the explicit prohibitions contained in Article 20 of the TRIPS Agreement and Article 2.2 of the TBT Agreement respectively must be read and, absent a conflict, applied together. The principle of harmonious reading dictates that the flexibilities implicitly left by those prohibitions also need to be viewed together, without a priori giving precedence to one over, and to the exclusion of, the other. ${ }^{62}$

The panel in the same case also referred, as discussed below, to the Doha Declaration as a "re-affirmation by Members of the flexibilities provided in the TRIPS Agreement in relation to measures taken for the protection of public health"; ${ }^{63}$ the concept of TRIPS flexibilities was also alluded to, for example, by Brazil and Thailand as third parties ${ }^{64}$ and by the panel itself (para. 7.2407 and 7.2408). Interestingly, the Appellate Body in Australia-Tobacco Plain Packaging referred to the concept of Members' 'regulatory autonomy' in encumbering the use of trademarks by special requirements under Article $20 .{ }^{65}$

\footnotetext{
${ }^{59}$ See, China-Intellectual Property Rights, para. 7.484, 7.493, 7.597, and 7.678.

${ }^{60}$ Idem, para. 7.199.

${ }^{61}$ Para 7.602.

${ }^{62}$ Australia-Tobacco Plain Packaging, para. 7.100.

${ }^{63}$ Idem, para. 7.2408.

${ }^{64} \mathrm{Idem}$, para. 7.2391 and 2387.

${ }^{65}$ Appellate Body Report, op. cit., para. 6.697.
} 


\section{Interpretation of the TRIPS Agreement ${ }^{66}$}

This section considers some principles for and aspects of the interpretation of the TRIPS Agreement particularly relevant for the application of the TRIPS flexibilities.

\subsection{Precedential Value of GATT/WTO Jurisprudence}

Neither the GATT nor the WTO jurisprudence have precedential value; however, even if unrelated to intellectual property, such jurisprudence may influence and provide guidance for future rulings on the TRIPS Agreement. ${ }^{67}$ One issue of particular relevance is whether jurisprudence on subjects other than those covered by this Agreement should be used to interpret it. The panel in India-Patent Protection for Pharmaceutical and Agricultural Chemical Products, for instance, held that although the TRIPS Agreement has a "relatively self-contained, sui generis status within the WTO," it also was "an integral part of the WTO system, which itself builds upon the experience of over nearly half a century under the GATT 1947." $" 68$ In United States-Section 110(5) of the U.S. Copyright Act, while the panel noted that caution was required when interpreting the TRIPS Agreement provisions in the light of precedents developed in GATT dispute settlement practice, it stated that

given that the agreements covered by the WTO form a single, integrated legal system, we deem it appropriate to develop interpretations of the legal protection conferred on intellectual property right holders under the TRIPS Agreement which are not incompatible with the treatment conferred to products under the GATT, or in respect of services and service suppliers under the GATS, in the light of pertinent dispute settlement practice. ${ }^{69}$

The application of general GATT and WTO jurisprudence to cases involving the TRIPS Agreement would ignore the specificity of intellectual property issues and one major difference between the TRIPS Agreement and other WTO covered agreements: the former provides for disciplines on intellectual property rights, which are private rights ${ }^{70}$ the exercise of which may restrain rather than facilitate international trade (as in the case of other WTO agreements). The private rights nature of intellectual property rights was highlighted in the panel report in ChinaIntellectual Property Rights:

\footnotetext{
${ }^{66}$ This section is partially based on Carlos Correa, op. cit., 2005, which examines other aspects, such as the role of the negotiating history and the application of prior intellectual property conventions incorporated into the TRIPS Agreement;-,; see also Kennedy (2016).

${ }^{67}$ See, e.g., Flowers (2019), pp. 90-104. See also, Howse (2000). Available from: https:// onlinelibrary.wiley.com/doi/abs/10.1111/j.1747-1796.2000.tb00139.x.

${ }^{68}$ Para. 7.19.

${ }^{69}$ Para. 6.185.

${ }^{70}$ See, the Preamble to the TRIPS Agreement, fourth paragraph.
} 
Viewed in context, the phrase "shall have the authority" does not require Members to take any action in the absence of an application or request. Therefore, a condition that authority shall only be available upon application or request seems to be assumed in much of Sections 2, 3 and 4 of Part III. This is consistent with the nature of intellectual property rights as private rights, as recognized in the fourth recital of the preamble of the TRIPS Agreement. Acquisition procedures for substantive rights and civil enforcement procedures generally have to be initiated by the right holder and not ex officio. ${ }^{71}$

One corollary of this, for instance, is that in contrast to the general GATT/WTO jurisprudence, the exceptions in the TRIPS Agreement need not to be read narrowly, but instead with the aim of achieving the objectives as defined in Article 7 (see below). Notably, intellectual property rights constitute exceptions in terms of Article $\mathrm{XX}(\mathrm{d})$ of GATT and, hence, their restrictive effects should not be augmented but mitigated through the interpretation of the scope and extent of the conferred exclusive rights. ${ }^{72}$ The exceptions to exclusive rights are crucial to preserve market dynamics and achieve a diversity of public interests; they are a key component of the TRIPS flexibilities. ${ }^{73}$

\subsection{Ordinary Meaning}

The GATT and WTO panels, as well as the WTO Appellate Body, have relied on the interpretive method codified by the Vienna Convention on the Law of the Treaties (VCLT). One of the basic steps for interpretation under Article 31 of the VCLT is the determination of the 'ordinary meaning' of the terms employed in the treaty, provided that "a special meaning shall be given to a term if it is established that the parties so intended" (Article 31.4). Many WTO panel and Appellate Body reports clearly indicate that such ordinary meaning is searched in the dictionary in order to clarify the scope and content of the relevant texts. ${ }^{74}$ Thus, the Appellate Body in EC-Chicken Cuts states: "The Appellate Body observed that dictionaries

are a useful starting point" for the analysis of 'ordinary meaning' of a treaty term, but they are not necessarily dispositive. The ordinary meaning of a treaty term must be ascertained according to the particular circumstances of each case. Importantly, the ordinary meaning

\footnotetext{
${ }^{71}$ Panel Report, IDS362, China-Measures Affecting the Protection and Enforcement of Intellectual Property Rights, op. cit., para 7.247. See also, para. 7.135. See also, para. 7.247, 7.135, 7.241, and 7.530; and Australia-Tobacco Plain Packaging, footnote 4472.

${ }^{72}$ See, e.g., Okediji (2017).

${ }^{73}$ Rodrigues Jr. (2012). https://www.researchgate.net/publication/288719106_The_general_excep tion_clauses_of_the_TRIPS_agreement_Promoting_sustainable_development.

${ }^{74}$ See, e.g., the elaboration DS 160 Panel Report, United States - Section 110(5) of US Copyright Act (2010); Appellate Body report DS 176, United States - Section 211 Omnibus Appropriations Act of 1998 (2002).
} 
of a treaty term must be seen in the light of the intention of the parties "as expressed in the words used by them against the light of the surrounding circumstances." ${ }^{75}$

\title{
In China-Intellectual Property Rights, the panel observed that
}

the general rule of treaty interpretation in Article 31 of the Vienna Convention refers in paragraph 1 to the ordinary meaning of the terms of the treaty, read in context. Where the terms are a single term, or ordinarily used together, then the treaty interpreter should refer to the ordinary meaning of that single term, or of each term in the particular context of each other. This is a distinct exercise from that in paragraph 4 of Article 31 of the Vienna Convention which requires a "special meaning" to be given to a term if it is established that the parties so intended. No party to this dispute considers that a "special meaning" should be given to the phrase "on a commercial scale," and nor does the Panel. ${ }^{76}$

While the rule regarding the ordinary meaning seems clear, an important question relates to the temporal aspect of the interpretation, that is, whether panels and Appellate Body should rely on the meaning of a term at the time of negotiation or adoption of an agreement, or whether they would be authorized to apply an evolutionary approach, that is, to rely on the meaning of a term at the time of its interpretation. Two approaches exist on this issue:

...the principle of contemporaneity, according to which the terms of a treaty are to be interpreted according to the meaning which they possessed, or which would have been attributed to them, and in the light of current linguistic usage, at the time when the treaty was originally concluded. Opposed to that is the dynamic approach, very often also labelled 'evolutionary' interpretation, which seeks to establish the meaning of a treaty at the time of its interpretation. ${ }^{77}$

In Canada-Patent Protection for Pharmaceutical Products, the panel examined the status of the legislation at the time of the negotiation of the Agreement to determine the concept of "legitimate interest" as contained in Article 30:

\begin{abstract}
Moreover, the Panel believed that it was significant that concerns about regulatory review exceptions in general, although well known at the time of the TRIPS negotiations, were apparently not clear enough, or compelling enough, to make their way explicitly into the recorded agenda of the TRIPS negotiation. The Panel believed that Article 30's "legitimate interests" concept should not be used to decide, through adjudication, a normative policy issue that is still obviously a matter of unresolved political debate. ${ }^{78}$
\end{abstract}

\footnotetext{
${ }^{75}$ Appellate Body Report in EC - Chicken Cuts, para. 175, quoting Appellate Body Report in US Softwood Lumber IV, para. 59, and referring to Appellate Body Reports in US - Offset Act (Byrd Amendment), para. 248, and US - Gambling, para. 166, and quoting McNair (1961), p. 365.

${ }^{76}$ Para 7.558 .

${ }^{77}$ Dörr and Schmalenbach (2012). Available from: https://link.springer.com/chapter/10.1007\% 2F978-3-642-19291-3_34, para. 58 (emphasis in the original), para. 23 (emphasis in the original). On the importance of the principle of "contemporaneity" in treaty interpretation, see also, Brownlie (1998), p. 627.

${ }^{78}$ Canada-Patent Protection for Pharmaceutical Products, para. 7.82.
} 
The WTO jurisprudence has adopted in some cases the evolutionary method of interpretation. ${ }^{79}$ In United States-Section 110(5) of the US Copyright Act, reference was made to the WIPO Copyright Treaty (WCT) adopted in 1996, 2 years after the TRIPS Agreement. The panel stated that the WCT should be viewed as "relevant to seek contextual guidance ... when developing interpretations that avoid conflicts within the overall multilateral copyright framework ..." ${ }^{80}$ Although it noted that the statement concerning WCT's Article 10 adopted by the signatory parties did not fall under the Vienna Convention rules on a subsequent agreement on the same matter or subsequent practice, the recourse to a post-TRIPS treaty to interpret a provision of the TRIPS Agreement constitutes a troubling precedent as long as it may lead to interpretations unduly expanding the Agreement's obligations. This is particularly the case in the light of technological developments and the increase of the level of protection beyond the standards of the TRIPS Agreement resulting from free trade agreements. $^{81}$

It is also worth noting that article 71 of the TRIPS Agreement specifically provides for the TRIPS Council to review the Agreement "in the light of any relevant new developments, which might warrant modification or amendment of this Agreement," thereby suggesting that any further 'developments' in intellectual property law need to be incorporated on the basis of WTO members' consensus, rather than via interpretation.

\subsection{Context}

In accordance with Article 31 of the VCLT, the terms in a treaty need to be considered taking their context into account. The preambles of WTO agreements have often been considered as the relevant context for the interpretation of particular provisions. ${ }^{82}$ In India-Patents (US), the Appellate Body referred to the Preamble of the TRIPS Agreement for the interpretation of Article 70.8(a): "The Panel's interpretation here is consistent with the object and purpose of the TRIPS Agreement." According to the Appellate Body, the object and purpose of the Agreement is, inter alia, "the need to promote effective and adequate protection of intellectual property rights." 83 References to the preamble were also made in China-Intellectual

\footnotetext{
${ }^{79}$ In United States - Import Prohibition of Certain Shrimp and Shrimp Products, WT/DS58/AB/R, para. 130 (1998), the Appellate Body held that certain terms in the WTO Agreements are not "static" but evolutionary, in relation to the term "exhaustible natural resources" as it appears in GATT Article XX(g) (para. 127, 130).

${ }^{80}$ United States-Section 110(5) of the U.S. Copyright Act, para. 6.70.

${ }^{81}$ See, e.g., Ruse-Khan (2017) (forthcoming, Netherlands Yearbook of International Law); Max Planck Institute for Innovation \& Competition Research Paper, No. 18-02; University of Cambridge Faculty of Law Research Paper, No. 3/2018. https://ssrn.com/abstract=3082718.

${ }^{82}$ See, e.g. Carlos Correa, op. cit., 2020, Chapter 1.

${ }^{83}$ See, https://www.wto.org/english/docs_e/legal_e/27-trips_02_e.htm.
} 
Property Rights. ${ }^{84}$ The Preamble of the Agreement on Technical Barriers to Trade was largely invoked as well by the panel in Australia-Tobacco Plain Packaging. ${ }^{85}$

The appropriate choice of treaty provisions that provide the context for interpreting other provisions is crucial. One example is the interpretation of Article 27.1 in fine. As noted above, the US initiated a case against Brazil arguing that Article 68 of the Brazilian patent law, which authorizes the government to grant a compulsory license if the patent owner fails to work the patent, was inconsistent with Article 27.1 in fine of the TRIPS Agreement. In accordance to this provisions, "patents shall be available and patent rights enjoyable without discrimination as to the place of invention, the field of technology and whether products are imported or locally produced." Key to addressing the US argument is identifying the context for the interpretation of this phrase in Article 27.1. In fact, this text incorporated a compromise reached, at the final stages of the negotiation of the Agreement, between developed and developing countries since the latter wanted to preserve the possibility of granting compulsory licenses for the lack or insufficient working of a patent. ${ }^{86}$

Developing countries expressed the concern that Article 27.1 could be read in a way that restricts the use of compulsory licenses, for instance, on the grounds of lack of working, as specifically provided for under Article 5A of the Paris Convention for the Protection of Industrial Property. In fact, the "patent rights" referred to in Article 27.1 are defined in Article 28.1, which only requires the granting of negative rights with regard to the exploitation of the invention, that is, the right to prevent third parties from using (without authorization) the patented invention. Hence, a proper interpretation of Article 27.1 read in conjunction with Article 28.1, based on the rules of the Vienna Convention, indicates that the products mentioned in Article 27.1 are infringing products, not the products of the patent owner itself, since patents only confer exclusionary and not positive rights. In other words, Article 27.1-if read in the context of Article 28 of the Agreement-forbids discrimination between infringing imported and infringing locally-made products, but it does not prevent the establishment of differential obligations with regard to non-infringing imported and locally-made products (i.e., products made or imported by the patent owner or with his/her consent). Hence, it does not outlaw compulsory licenses for lack of working.

The principle of "effective interpretation" (or "l'effet utile") requires that a treaty must be interpreted in such a way as to give meaning and effect to all the terms of the treaty. This is certainly possible with respect to Article 27.1 in fine. This non-discrimination clause may apply, for instance, to a case in which the rights enjoyed by patent owners differ depending on whether the alleged infringing goods have been locally produced or imported. For instance, Section 337 of the U.S. Tariff Act was found inconsistent with the GATT in United States-Section 337 of the

\footnotetext{
${ }^{84}$ See, para. 7.135 .

${ }^{85}$ See, e.g., para. 7.2398 .

${ }^{86}$ UNCTAD and ICTSD (2005), p. 467. https://unctad.org/en/PublicationsLibrary/ictsd2005d1_en. pdf.
} 
Tariff Act of 1930, since it accorded less favorable treatment to imported products challenged as infringing on US patents than the treatment accorded to similarly challenged products of United States origin. ${ }^{87}$

Another example in which the correct identification of the context for a provision may have decisive effects relates to Article 39.3, which has been interpreted by the US and the European Commission as requiring the grant of exclusive rights ('data exclusivity') with respect to test data for pharmaceuticals and agrochemical products. This interpretation is clearly inviable in light of Article 39.1 which provides an essential contextual element and only requires protection against unfair commercial practices, which does not entail such exclusive rights. ${ }^{88}$

In engaging in the difficult task of clarifying the meaning of 'unjustifiably' in Article 20 of the TRIPS Agreement, the panel in Australia-Tobacco Plain Packaging elaborated on the context of that provision. It specifically alluded to the Preamble and Articles 7 and 8 of the Agreement:

We first note that the first recital of the preamble to the TRIPS Agreement expresses a key objective of the TRIPS Agreement, namely to "reduce distortions and impediments to international trade" and takes into account the need, on one hand, "to promote effective and adequate protection of intellectual property rights" and, on the other, "to ensure that measures and procedures to enforce intellectual property rights do not themselves become barriers to legitimate trade" (para. 7.2398).

We also consider that Article 7 entitled "Objectives" and Article 8 entitled "Principles" provide relevant context (para 7.2399).

Articles 7 and 8, together with the preamble of the TRIPS Agreement, set out general goals and principles underlying the TRIPS Agreement, which are to be borne in mind when specific provisions of the Agreement are being interpreted in their context and in light of the object and purpose of the Agreement. As the panel in Canada - Pharmaceutical Patents observed in interpreting the terms of Article 30 of the TRIPS Agreement, "[b]oth the goals and the limitations stated in Articles 7 and 8.1 must obviously be borne in mind when doing so as well as those of other provisions of the TRIPS Agreement which indicate its object and purposes" (para. 7.2402).

The panel further elaborated on the 'balance' suggested by Articles 7 and 8.1 of the TRIPS Agreement and, in particular, on the fact that the Agreement did not intend to prevent WTO members from adopting measures to protect public interests, such as public health. It stated:

Article 7 reflects the intention of establishing and maintaining a balance between the societal objectives mentioned therein. Article 8.1, for its part, makes clear that the provisions of the TRIPS Agreement are not intended to prevent the adoption, by Members, of laws and regulations pursuing certain legitimate objectives, specifically, measures "necessary to protect public health and nutrition" and "promote the public interest in sectors of vital importance to their socio-economic and technological development," provided that such measures are consistent with the provisions of the Agreement (para. 7.2403).

\footnotetext{
${ }^{87}$ See, e.g., Haedicke (2000), p. 1774.

${ }^{88}$ See, e.g., Correa (2011b).
} 
Article 8 offers, in our view, useful contextual guidance for the interpretation of the term "unjustifiably" in Article 20. Specifically, the principles reflected in Article 8.1 express the intention of drafters of the TRIPS Agreement to preserve the ability for WTO Members to pursue certain legitimate societal interests, at the same time as it confirms their recognition that certain measures adopted by WTO Members for such purposes may have an impact on IP rights, and requires that such measures be "consistent with the provisions of the [TRIPS] Agreement” (para. 7.2404).

The specific objectives expressly identified in Article 8.1 do not, in our view, necessarily exhaust the scope of what may constitute a valid basis for the "justifiability" of encumbrances on the use of trademarks under Article 20. However, their identification in Article 8.1 may shed light on the types of recognized "societal interests" that may provide a basis for the justification of measures under the specific terms of Article 20, and unquestionably identify public health as such a recognized societal interest (para. 7.2406).

In summary, while the Preamble and Articles 7 and 8 of the TRIPS Agreement provide the context for the interpretation of all its provisions, as suggested by the examples above, the careful choice of other specific provisions to examine the scope and extent of particular obligations is key to preserving the flexibilities under that agreement.

\subsection{Object and Purpose}

As noted, the interpretative method codified by the VCLT - as spelled out in Articles 31 and 32 of the VCLT - relies on the textual interpretation of treaty provisions. The reference, however, to the 'object and purpose' of the treaty as one of the elements for interpretation has been understood by some courts as leaving room to consider the 'intention' of the negotiating parties or to apply a teleological approach. ${ }^{89}$ It has been noted, for instance, that the European Court of Human Rights, "has developed its own version of these rules of interpretation-a version that tracks the three traditional approaches to treaty interpretation: the textual approach, the subjective approach, and the teleological approach. ${ }^{90}$ However, as noted by two commentators,

The consideration of object and purpose finds its limits in the ordinary meaning of the text of the treaty. It may only be used to bring one of the possible ordinary meanings of the terms to prevail and cannot establish a reading that clearly cannot be expressed with the words used in the text. ${ }^{91}$

The quoted authors note in this regard the opinion in the Iran-US Claims Tribunal which pointed out:

Even when one is dealing with the object and purpose of a treaty, which is the most important part of the treaty's context, the object and purpose does not constitute an element

\footnotetext{
${ }^{89}$ Linderfalk (2007), p. 205. https://www.corteidh.or.cr/tablas/r32592.pdf.

${ }^{90}$ See, e.g., Dothan (2019), p. 765; iCourts Working Paper Series, No. 141. https://ssrn.com/ abstract $=3241331$.

${ }^{91}$ Oliver Dörr and Kirsten Schmalenbach, op. cit., para 58.
} 
independent of that context. The object and purpose is not to be considered in isolation from the terms of the treaty; it is intrinsic to its text. It follows that, under Article 31 of the Vienna Convention, a treaty's object and purpose is to be used only to clarify the text, not to provide independent sources of meaning that contradict the clear text. ${ }^{92}$

In the case of the WTO agreements, adherence to the treaty text and avoiding 'activism' in the interpretation of their provisions is of utmost importance-as shown by recent debates on the functioning of the Appellate Body ${ }^{93}$ - so as not to expand the Members' obligations or create new ones, and to provide certainty to their trade relations.

Notably, under Article 4.2 of the Dispute Settlement Understanding ("DSU”), panels and the Appellate Body are mandated to 'clarify' the various WTO agreements, and in doing so they cannot add to or diminish the rights and obligations provided in such agreements. Moreover, Article 4.9 provides that the DSU does not prejudice a government's right to seek an 'authoritative interpretation' of any of those agreements from the Ministerial Conference or General Council of the WTO. Hence, the WTO attempts to introduce a difficult distinction between 'clarification' and 'interpretation.' The panels and Appellate Body reports regularly note, however, that they 'interpret' the provisions invoked by the members in accordance to the VLCT rules. This has indeed been the case in those disputes referring to the TRIPS Agreement. $^{94}$

However, although the literal interpretation is the basic rule of interpretation under Article 31 (1) of the VCLT as recognized in the Convention itself, in some cases the textual reading of a provision or a term thereof in its context may still leave ambiguity as to the legal meaning of a text. At this point, the identification of the 'object and purpose' of the treaty, conceived as part of the literal interpretation and not as a separate step, acquires particular importance. It is difficult to think of judgments that are absolutely neutral in terms of the policy objectives enshrined in the treaty.

Identifying the object and purpose of the TRIPS Agreement is different from characterizing the purpose of intellectual property rights, as the objectives pursued by governments with these rights, as well as the way of implementing them, may differ significantly, even while they comply with the standards of the Agreement and other applicable international treaties). There is no global, uniform system of intellectual property protection.

In Canada-Patent Protection for Pharmaceutical Products, the panel elaborated on the policy objective of patent laws. It stated:

The normal practice of exploitation by patent owners, as with owners of any other intellectual property right, is to exclude all forms of competition that could detract significantly from the economic returns anticipated from a patent's grant of market exclusivity ... Patent laws

\footnotetext{
${ }^{92}$ Iran-United States Claims Tribunal, Federal Reserve Bank of New York v. Bank Markazi (n 19) para 58.

${ }^{93}$ See, e.g., Danish and Aileen Kwa, op. cit.

${ }^{94}$ See, e.g., M. Kennedy, op. cit., 2016.
} 
establish a carefully defined period of market exclusivity as an inducement to innovation, and the policy of those laws cannot be achieved unless patent owners are permitted to take effective advantage of that inducement once it has been defined. ${ }^{95}$

This view seems to suggest that obtaining 'economic returns' as an 'inducement to innovation' is what underpins patent policies. It is not consistent with the purpose of the TRIPS Agreement as reflected in Articles 7 and 8. This approach overlooks that patents, as well as other intellectual property rights, can and should be designed and implemented to achieve public rather than private interests, including the diffusion of technical knowledge, technological progress, and access to the outcomes of innovation. ${ }^{96}$ Thus, in 1917, the US Supreme Court noted that "the primary purpose of that [patent] law is not to create private fortunes, but is to promote the progress of science and the useful arts.",97

Articles 7 ('Objectives') and 8 ('Principles') of the TRIPS Agreement are key for the determination of the object and purpose of the Agreement, in conjunction, as discussed below, with the Doha Declaration as a subsequent agreement among the parties. Importantly, those provisions are not just hortatory provisions ${ }^{98}$ but have been incorporated-upon the demand of developing countries during the negotiations ${ }^{99}$ - among the prescriptive provisions of the Agreement.

In Canada-Patent Term, the Appellate Body referred to the need to interpret Article 70.1 of the Agreement as having particular regard to the object and purpose of the treaty, but it eluded an interpretation and application of Articles 7 and 8:

[W]e note that our findings in this appeal do not in any way prejudge the applicability of Article 7 or Article 8 of the TRIPS Agreement in possible future cases with respect to measures to promote the policy objectives of the WTO Members that are set out in those Articles. Those Articles still await appropriate interpretation. ${ }^{100}$

The Panel Report in Canada-Pharmaceutical Patents dealt more specifically with the question of the 'object and purpose' of the TRIPS Agreement. It relied to this end on Articles 7 and 8 for that determination, but in conjunction with other provisions of the Agreement. It stated:

Article 30's very existence amounts to a recognition that the definition of patent rights contained in Article 28 would need certain adjustments. On the other hand, the three limiting conditions attached to Article 30 testify strongly that the negotiators of the Agreement did not intend Article 30 to bring about what would be equivalent to a renegotiation of the basic balance of the Agreement. Obviously, the exact scope of Article 30's authority will depend on the specific meaning given to its limiting conditions. The words of those conditions must

\footnotetext{
${ }^{95}$ Canada-Patent Protection for Pharmaceutical Products, supra note 23, para. 7.55.

${ }^{96}$ See, paragraph 4 of the Doha Declaration.

${ }^{97}$ Motion Picture Patents Co. v. Universal Film Co. [1917] 243 U. S. 502.

${ }^{98}$ See, e.g., "TRIPS provisions as interpreted by the WTO dispute settlement organs", Law Explorer. https://lawexplores.com/trips-provisions-as-interpreted-by-the-wto-dispute-settlementorgans/.

${ }^{99}$ See, Carlos Correa, op. cit., 2020, pp. 83-95.

${ }^{100}$ Appellate Body Report, Canada - Term of Patent Protection, WT/DS170/AB/R (18 September 2000), para. 101. https://www.wto.org/english/tratop_e/dispu_e/170abr_e.pdf.
} 
be examined with particular care on this point. Both the goals and the limitations stated in Articles 7 and 8.1 must obviously be borne in mind when doing so as well as those of other provisions of the TRIPS Agreement which indicate its object and purposes. ${ }^{101}$

It is unclear what "other provisions of the TRIPS Agreement which indicate its object and purposes" are suggested by the panel. While there might be different perceptions about the object and purpose of the TRIPS Agreement - as the debates between developed and developing countries have shown during the negotiation and after the adoption of the TRIPS Agreement ${ }^{102}$ — the panels and Appellate Body need to be guided by the text of the Agreement and not by the individual views of the members of those bodies.

Paragraph 5(a) of the Doha Declaration confirmed the importance of Articles 7 and 8 for the interpretation of the TRIPS Agreement:

Accordingly and in the light of paragraph 4 above, while maintaining our commitments in the TRIPS Agreement, we recognize that these flexibilities include:

a. In applying the customary rules of interpretation of public international law, each provision of the TRIPS Agreement shall be read in the light of the object and purpose of the Agreement as expressed, in particular, in its objectives and principles.

The wording of this paragraph ("in particular") suggests that while Articles 7 and 8 are determinant in defining the object and purpose of the Agreement, other provisions of the Agreement, as well as the preambular provisions, can also contribute to the determination of its object and purpose. Such may be the case, for instance, of Article 41.2 which states: "Procedures concerning the enforcement of intellectual property rights shall be fair and equitable ..." This provision makes it clear that one purpose of the Agreement is to ensure that the enforcement of intellectual property rights (as mandated in Part III of the Agreement) is 'fair and equitable' to all the parties concerned, and that it does not provide undue advantages to the right holders over third parties in judicial or administrative procedures, or vice versa.

An interesting elaboration on the object and purpose of the TRIPS Agreement based on Articles 7 and 8 was undertaken by the panel in Australia-Tobacco Plain Packaging. ${ }^{103}$ The panel largely relied on the Doha Declaration to address this issue. It noted:

We note in this respect that the Doha Declaration, adopted by Ministers on 14 November 2001, provides that, "[i]n applying the customary rules of interpretation of public international law, each provision of the TRIPS Agreement shall be read in the light of the object and purpose of the Agreement as expressed, in particular, in its objectives and principles" (para. 7.2407).

While this statement was made in the specific context of a re-affirmation by Members of the flexibilities provided in the TRIPS Agreement in relation to measures taken for the protection of public health, we note that paragraph 5 of the Doha Declaration is formulated in

\footnotetext{
${ }^{101}$ See, Canada-Patent Protection for Pharmaceutical Products, supra note 23, para. 7.26.

${ }^{102}$ Shadlen (2004). Available from: https://link.springer.com/article/10.1007\%2FBF02686283.

${ }^{103}$ Romero (2020b). Available from: https://www.southcentre.int/policy-brief-79-june-2020/.
} 
general terms, inviting the interpreter of the TRIPS Agreement to read "each provision of the TRIPS Agreement" in the light of the object and purpose of the Agreement, as expressed in particular in its objectives and principles. As described above, Articles 7 and 8 have central relevance in establishing the objectives and principles that, according to the Doha Declaration, express the object and purpose of the TRIPS Agreement relevant to its interpretation (7.2408).

The Appellate Body essentially followed the panel's views on this matter. It clarified, however, that the conclusions reached regarding the purpose of the TRIPS Agreement are supported by Articles 7 and 8, and that the analysis of the Doha Declaration reconfirmed the panel's findings. It held:

The Panel also remarked that the societal interests referred to in Article 8 may provide a basis of the justification of measures under Article 20. Thus, we agree with Australia that, in any event, the reliance on the Doha Declaration was not of decisive importance for the Panel's reasoning since the Panel had reached its conclusions about the contextual relevance of Articles 7 and 8 of the TRIPS Agreement to the interpretation of Article 20 before it turned to the Doha Declaration. The Panel relied on the Doha Declaration simply to reconfirm its previous conclusions regarding the contextual relevance of Articles 7 and 8 of the TRIPS Agreement (6.658).

This analysis and the observations above show that the WTO case law has considered Articles 7 and 8, both as part of the context for interpretation and as defining elements of the object and purpose of the TRIPS Agreement. It confirms the relevance of said provisions for the interpretation of other provisions in the Agreement.

\subsubsection{Legal Weight of the Doha Declaration}

In order to give authority to its argument regarding the relevance of Articles 7 and 8 for the interpretation of the TRIPS Agreement's provisions, the panel in Australia-Tobacco Plain Packaging specifically elaborated on the legal weight of the Doha Declaration. This is one of the most distinct (and welcome) contributions of this panel's report, as it is the first time in which the normative effects of that Declaration have been considered in WTO jurisprudence.

In some WTO disputes prior to the Australia tobacco case, the issue of subsequent practices as an element for interpretation of the TRIPS provisions was very cautiously considered. Thus, in Canada-Patent Protection for Pharmaceutical Products, the panel considered comparative law in order to determine whether the interest claimed as "legitimate" by the EC was a "widely recognized policy norm." United States-Section 110(5) of the US Copyright Act, the panel confirmed its conclusion with reference to examples of "state practice" of members of the Berne Union and WTO, but it warned that it "did not wish to express a view on whether these are sufficient to constitute 'subsequent practice' within the meaning of Article

${ }^{104}$ Para.7.77. 
31(3)(b) of the Vienna Convention."105 In China-Intellectual Property Rights, the panel rejected certain material submitted by China to prove a "subsequent practice" in the application of the TRIPS Agreement within the meaning of Article 31(3) of the Vienna Convention. The panel considered that it lacked "the breadth to constitute a common, consistent, discernible pattern of acts or pronouncements" and that "the content of the material does not imply agreement on the interpretation of Article 61 of the TRIPS Agreement.",106

A key panel assertion in the referenced case against Australia is that the Doha Declaration must be considered a 'subsequent agreement' as defined in the VCLT. ${ }^{107}$ In accordance with Article 31.3(a) of the VCLT, "any subsequent agreement between the parties regarding the interpretation of the treaty or the application of its provisions" shall be taken into account, together with the context. ${ }^{108}$ It is worth noting that the International Law Commission adopted in its 2018 report "Draft Conclusions on Subsequent Agreements and Subsequent Practice in Relation to the Interpretation of Treaties" 109 which, in accordance with one commentator, suggests a "subtle elevation of subsequent agreement and subsequent practice," which would thereby become an integral part of the main rule of interpretation. ${ }^{110}$

In making reference to the Appellate Body ruling in US - Clove Cigarettes (para. 262), the panel stated:

This paragraph of the Doha Declaration may, in our view, be considered to constitute a "subsequent agreement" of WTO Members within the meaning of Article 31(3)(a) of the Vienna Convention. As the Appellate Body has clarified:

Based on the text of Article 31(3)(a) of the Vienna Convention, we consider that a decision adopted by Members may qualify as a "subsequent agreement between the parties" regarding the interpretation of a covered agreement or the application of its provisions if: (i) the decision is, in a temporal sense, adopted subsequent to the relevant covered agreement; and (ii) the terms and content of the decision express an agreement between Members on the interpretation or application of a provision of WTO law (para. 7.2409).

The panel's view rebuts the United States Trade Representative' (USTR) opinion expressed upon the conclusion of the Doha Conference that the Doha Declaration merely was a "political declaration."111 As noted by a commentator, "[d] istinguishing legal claims from non-legal or political claims, such as access to

\footnotetext{
${ }^{105}$ See, United States-Section 110(5) of the U.S. Copyright Act, para. 6.55, n. 68.

${ }^{106}$ Para. 7.581.

${ }^{107}$ For an early analysis on this subject, see, Correa (2002), p. 45. https://apps.who.int/iris/handle/ $10665 / 67345$.

${ }^{108}$ See, e.g., Stefan Kadelbach (2018). http://www.qil-qdi.org/international-law-commission-androle-of-subsequent-practice-as-a-means-of-interpretation-under-articles-31-and-32-vclt/.

${ }^{109}$ United Nations (2018). https://legal.un.org/ilc/reports/2018/english/a_73_10_advance.pdf.

${ }^{110}$ Tladi (2018). https://www.ejiltalk.org/is-the-international-law-commission-elevating-subse quent-agreements-and-subsequent-practice/.

${ }^{111}$ USTR Fact Sheet Summarizing Results from WTO Doha Meeting, 15 November 2001.
} 
essential medicines, can deprive them of their status as rights and thereby serve to legitimize an unjust status quo." 112

The panel further explored the legal status of the Doha Declaration under WTO law, noting that although being a 'declaration,' it was adopted by a consensus decision at the WTO Conference. The panel argued as follows:

In this instance, the instrument at issue is a "declaration," rather than a "decision." However, the Doha Declaration was adopted by a consensus decision of WTO Members, at the highest level, on 14 November 2001 on the occasion of the Fourth Ministerial Conference of the WTO, subsequent to the adoption of the WTO Agreement, Annex 1C of which comprises the TRIPS Agreement. The terms and contents of the decision adopting the Doha Declaration express, in our view, an agreement between Members on the approach to be followed in interpreting the provisions of the TRIPS Agreement. This agreement, rather than reflecting a particular interpretation of a specific provision of the TRIPS Agreement, confirms the manner in which "each provision" of the Agreement must be interpreted, and thus "bears specifically" on the interpretation of each provision of the TRIPS Agreement (7.2410).

This paragraph reiterates the characterization of the Doha Declaration as a 'subsequent agreement' under the VCLT and adds two important elements: its adoption 'at the highest level' and an agreement 'on the approach' to be followed in interpreting each provision of the Agreement. This 'approach' is reflected in paragraph 5(a) of the Declaration quoted above but also in the rest of the Declaration, particularly as it makes a clear case for protecting public health, a key public interest and a matter of respect and realization of human rights, in implementing the TRIPS Agreement. ${ }^{113}$

The panel's analysis on the Doha Declaration does not aim, however, at asserting its legal value per se but its role as a confirmation that Articles 7 and 8 of the TRIPS Agreement provide both the context and define the object and purpose of the Agreement. The panel stated in this regard:

The guidance provided by the Doha Declaration is consistent, as the Declaration itself suggests, with the applicable rules of interpretation, which require a treaty interpreter to take account of the context and object and purpose of the treaty being interpreted, and confirms in our view that Articles 7 and 8 of the TRIPS Agreement provide important context for the interpretation of Article 20 (7.2411).

The analysis of the legal status of the Doha Declaration is one of the most significant contributions by the panel in Australia-Tobacco Plain Packaging. It supported the panel's conclusion with respect to the justifiability of the plain packaging measures adopted by that country and, hence, their consistency with Article 20 of the TRIPS Agreement. ${ }^{114}$

${ }^{112}$ Gathii (2002), p. 315. https://pdfs.semanticscholar.org/a3a6/65016915476d1088 fea2e7f4e97baf2f0f03.pdf.

${ }^{113}$ See, e.g., Carlos Correa, op cit., 2002; Velasquez, Correa, and Ido, op. cit, 2020; UNDP (2015a). https://www.undp.org/content/undp/en/home/librarypage/hiv-aids/doha10yearson.html.

${ }^{114}$ Romero (2020a). https://www.southcentre.int/research-paper-108-april-2020/. 


\section{Conclusions}

The notion that the TRIPS Agreement is not a uniform law and that it allows WTO members some room to maneuver in interpreting and implementing the Agreement's obligations is well established in the literature and numerous resolutions by UN agencies and bodies. The adoption of the Doha Declaration, and several rulings by panels and the Appellate Body, point in the same direction. An evolution is perceptible in the WTO jurisprudence on the matter. In particular, the most recent panel report in Australia-Tobacco Plain Packaging shows the explicit acceptance of the concept of TRIPS flexibilities in WTO case law and their role in preserving the required policy space to pursue public policies such as public health. This is an important development that could provide the basis for a further step in that jurisprudence: the integration of human rights law, as a component of international law, in the analysis of the obligations imposed by that Agreement and of the leeway that states should preserve for the realization of such rights. ${ }^{115}$

The extent to which the TRIPS flexibilities can be implemented at the national level without the risk of trade retaliations depends on the way the Agreement's provisions are interpreted by panels and the Appellate Body. Several issues need to be addressed in considering how such provisions should be interpreted, consistently with the interpretive method codified by the VCLT. While the search for the ordinary meaning of the terms used is a well-established methodology, divergences may exist with regard to whether they should be deemed as 'static' or 'evolutionary.' An evolutionary approach creates the risk of unduly expanding the obligations under the Agreement, as actively promoted by some developed countries through free trade agreements. The adequate determination of the context-beyond the Preamble and Articles 7 and 8-for interpretation of a particular provision is also important, as it may decisively influence the determination of the scope and extent of the obligation under the Agreement. Similarly, the understanding on the object and purpose of the Agreement plays an important role. The WTO jurisprudence seems to have firmly admitted that such a determination is to be based on said Articles 7 and 8 .

The impact of the TRIPS Agreement on public health and, particularly, access to medicines has been one of the most sensitive issues since its adoption. This issue has been key in promoting debates and analyses on the TRIPS flexibilities (although they are also important in relation to other public interests, such as access to knowledge or food security). In this regard, the panel ruling in the case against Australia on plain packaging has confirmed the legal status of the Doha Declaration—seen by some as a merely political instrument-as a 'decision' taken by consensus that constitutes a 'subsequent agreement' among the WTO members. This is also an important development as it suggests that a pro-public health interpretation is not only tenable but also mandated, and confirms the room that

\footnotetext{
${ }^{115}$ See, e.g., Sellin (2015), pp. 445-473. https://link.springer.com/article/10.1007/s40802-0150047-5.
} 
governments have to confidently adopt pro-public health measures without fearing the risk of costly and burdensome litigation under the DSU.

\section{References}

Brownlie I (1998) Principles of public international law. p. 627

Correa C (2002) Implications of the Doha Declaration on the TRIPS agreement and public health. World Health Organization, Geneva, p 45. Available from https://apps.who.int/iris/handle/ $10665 / 67345$

Correa C (2005) The TRIPS Agreement from the perspective of developing countries. In: Macrory P, Appleton A, Plummer M (eds) The World Trade Organization: legal, economic and political analysis. Springer, Berlin, p 2005

Correa C (2011a) Globalisation and intellectual property rights. The struggle of developing countries to influence TRIPS. In: Alam S, Klein N, Overland J (eds) Globalisation and the quest for social and environmental justice: the relevance of international law in an evolving World Order. Routledge, Milton Park

Correa C (2011b) Test data protection: rights conferred under the TRIPS Agreement and some effects of TRIPS-plus standards. In: Dreyfuss RC, Strandburg KJ (eds) The law and theory of trade secrecy. A handbook of contemporary research. Edward Elgar, Cheltenham

Correa C (2014) Patent protection for plants: legal options for developing countries. Research Paper No. 55. South Centre, Geneva. Available from https://www.southcentre.int/wp-content/uploads/ 2014/11/RP55_Patent-Protection-for-Plants_EN.pdf

Correa C (2020a) Special Section 301: US interference with the design and implementation of National Patent Laws. Research Paper 115. South Centre, Geneva. Available from https:// www.southcentre.int/research-paper-115-july-2020/

Correa C (2020b) Trade Related Aspects of Intellectual Property Rights. A commentary on the TRIPS Agreement, 2nd edn. Oxford University Press, p 21

Danish and Aileen Kwa (2019) Crisis at the WTO's Appellate Body (AB): why the AB is important for developing members. Policy Brief No. 69. South Centre, Geneva. Available from https:// www.southcentre.int/wp-content/uploads/2019/12/PB69_Crisis-at-the-WTO\%E2\%80\%99sAppellate-Body-AB-Why-the-AB-is-Important-for-Developing-Members_EN-1.pdf

Dörr O, Schmalenbach K (2012) Article 31. General rule of interpretation. In: Vienna Convention on the law of treaties - a commentary. Springer, Berlin. Available from https://link.springer. com/chapter/10.1007\%2F978-3-642-19291-3_34

Dothan S (2019) The three traditional approaches to treaty interpretation: a current application to the European Court of Human Rights. Fordham Int Law J 42:765; iCourts Working Paper Series, No. 141. Available from: https://ssrn.com/abstract $=3241331$

Eger T, Scheufen M (2012) The past and the future of copyright law: technological change and beyond”. In Liber Amicorum Boudewijn Bouckaert. Die Keure. Available from https://www. researchgate.net/publication/280043122_The_past_and_the_future_of_copyright_law_techno logical_change_and_beyond

European Commission (2020) Report on the protection and enforcement of intellectual property rights in third countries. Commission staff working document. Available from https://trade.ec. europa.eu/doclib/docs/2020/january/tradoc_158561.pdf

Flowers Z (2019) The role of precedent and stare decisis in the World Trade Organization's dispute settlement body. Int J Legal Information 47(2):90-104

Fuchs S (2020) COVID-19: New German legislation to fight pandemic may affect granted German patents. Available from https://www.twobirds.com/en/news/articles/2020/germany/covid-19new-german-legislation-to-fight-pandemic-may-affect-granted-patents 
Gathii JT (2002) The legal status of the Doha Declaration on TRIPS and public health under the Vienna Convention of the Law of Treaties. Harv J Law Technol 15(2):315. Available from https://pdfs.semanticscholar.org/a3a6/65016915476d1088fea2e7f4e97baf2f0f03.pdf

Geiger C, Gervais D, Senftleben M (2013) The three-step test revisited: how to use the test's flexibility in national copyright law. PIJIP Research Paper Series. Available from https:// digitalcommons.wcl.american.edu/cgi/viewcontent.cgi?article $=1041 \&$ context $=$ research

Germán Velásquez (2013) Access to medicines and intellectual property: the contribution of the World Health Organization. Research Paper No. 47. South Centre, Geneva, p 5. Available from https://www.southcentre.int/wp-content/uploads/2013/05/RP47_WTO-role-in-IP-and-accessto-medicines_EN.pdf

Germán Velásquez (2019) Medicines and intellectual property: 10 years of the WHO global strategy. Research Paper No. 100. South Centre, Geneva

Haedicke M (2000) U.S. imports, TRIPS and Section 337 of the Tariff Act of 1930. Int Rev Indus Property Copyright Law 31(7/8):1774

Howse R (2000) The Canadian medicine panel: a dangerous precedent in dangerous times. J World Intellectual Property 3(4). Available from https://onlinelibrary.wiley.com/doi/abs/10.1111/j. 1747-1796.2000.tb00139.x

Kadelbach S (2018) The International Law Commission and role of subsequent practice as a means of interpretation under Articles 31 and 32 VCLT. Questions of International Law. Available from http://www.qil-qdi.org/international-law-commission-and-role-of-subsequent-practice-asa-means-of-interpretation-under-articles-31-and-32-vclt/

Kennedy M (2016) WTO dispute settlement and the TRIPS agreement: applying intellectual property standards in a trade law framework. Cambridge University Press, Cambridge

Linderfalk U (2007) On the interpretation of treaties: the modern international law as expressed in the 1969 Vienna Convention on the Law of Treaties. Springer, Berlin, p 205. Available from https://www.corteidh.or.cr/tablas/r32592.pdf

McNair (1961) The law of treaties. Clarendon Press, Oxford, p 365

Mgbeoji I (2006) Global biopiracy: patents, plants, and indigenous knowledge. UBC Press, Vancouver. Available from https://books.google.fr/books?id=q4MIoBKy88MC\& $\mathrm{pg}=\mathrm{PA} 121 \& \mathrm{lpg}=\mathrm{PA} 121 \& \mathrm{dq}=$ biopiracy $+\mathrm{us}+$ patents $\&$ source $=$ bl\&ots $=-\mathrm{ZBMOhXLLn} \&$ sig $=$ ACfU3U0DslCI-lxiwQuSmN-jeuuC-fafLQ\&hl=en\&sa $=$ X\&ved $=2$ ahUKEwitsrmu8N pAhUSx4UKHe1_DHYQ6AEwEnoECAkQAQ\#v=onepage\&q=biopiracy\%20us\%20pat ents\&f $=$ false

Minn M (2016) Patenting of genetic research in Europe and the U.S.: a questionable future for diagnostic methods and personalized medicines. Biotechnology Law Report 38(2). Available from https://www.liebertpub.com/doi/10.1089/blr.2019.29108.mm

Morin J-F, Surbeck J (2020) Mapping the new frontier of international IP law: introducing a TRIPsplus dataset. World Trade Rev 19(1)

Okediji RL (ed) (2017) Copyright law in an age of limitations and exceptions. Cambridge University Press, Cambridge. Available from https://books.google.fr/books? $\mathrm{id}=31 \mathrm{pEDgAAQBAJ} \& \mathrm{pg}=\mathrm{PA} 241 \& \mathrm{lpg}=\mathrm{PA} 241 \& \mathrm{dq}=$ copyright+exception+interpretation + article $+30+$ ruth $\&$ source $=$ bl\&ots $=7$ MCIdWRbq7 \&sig $=$ ACfU 3 U $2 \mathrm{kCly} 0$ QaU z P X h b 83 g b 8 Q c S F 8 Utw \& h $1=e n \& s$ a $=$ X \& ved $=2$ a h U K Ew j U 4 N C b y zpAhURnxQKHXg0AtoQ6AEwBHoECAkQAQ\#v=onepage\&q=copyright\%20exception\% 20interpretation $\% 20$ article $\% 2030 \% 20$ ruth \&f=false

Prifti V (2015) The breeder's exception to patent rights - analysis of compliance with article 30 of the TRIPS Agreement. Springer, Berlin

Reid J (2019) Biopiracy: the struggle for traditional knowledge rights. Am Indian Law Rev 34(1). Available from https://digitalcommons.law.ou.edu/cgi/viewcontent.cgi?article=1121\& context=ailr

Rodrigues EB Jr (2012) The general exception clauses of the TRIPS agreement: promoting sustainable development. Cambridge University Press, Cambridge. Available from https:// 
www.researchgate.net/publication/288719106_The_general_exception_clauses_of_the_ TRIPS_agreement_Promoting_sustainable_development

Romero T (2020a) Public health and plain packaging of tobacco: an intellectual property perspective. Research Paper No. 108. South Centre, Geneva. Available from: https://www.southcentre. int/research-paper-108-april-2020/

Romero T (2020b) Articles 7 and 8 as the basis for interpretation of the TRIPS Agreement. Policy Brief No. 79. South Centre, Geneva. Available from https://www.southcentre.int/policy-brief79-june-2020/

Ruse-Khan HG (2017) From TRIPS to FTAs and back: re-conceptualising the role of a multilateral IP framework in a TRIPS-plus world. Forthcoming, Netherlands Yearbook of International Law; Max Planck Institute for Innovation \& Competition Research Paper, No. 18-02; University of Cambridge Faculty of Law Research Paper, No. 3/2018. Available from: https://ssrn.com/ abstract $=3082718$

Ruse-Khan HG, Puutio TA (2017) A handbook on negotiating development oriented intellectual property provisions in trade and investment agreements. UNESCAP, Bangkok, p 10. Available from https://www.unescap.org/sites/default/files/IPR\%20Handbook.pdf

Sellin JA (2015) Does one size fit all? Patents, the right to health and access to medicines. Netherlands Int Law Rev 62:445-473. Available from https://link.springer.com/article/10. 1007/s40802-015-0047-5

Shadlen K (2004) Patents and pills, power and procedure: the north-south politics of public health in the WTO. St Comp Int Dev 39, 76-108. Available from https://link.springer.com/article/10. 1007\%2FBF02686283

Shaikh OH (2016) Access to medicine versus test data exclusivity - Safeguarding flexibilities under international law. Springer, Berlin

Son KB, Lopert R, Gleeson D, Lee TJ (2018) Moderating the impact of patent linkage on access to medicines: lessons from variations in South Korea, Australia, Canada, and the United States. Globalization and Health vol. 14. Available from https://doi.org/10.1186/s12992-018-0423-0

The Graduate Institute Geneva, Knowledge Portal on Innovation and Access to Medicines. Available from: https://www.knowledgeportalia.org/. Last accessed 12 Feb 2021

The Law Library of Congress, Global Legal Research Center (2016) Patent Term Extensions and Adjustments

Tladi D (2018) Is the International Law Commission elevating subsequent agreements and subsequent practice? EJIL:Talk! Available from https://www.ejiltalk.org/is-the-international-lawcommission-elevating-subsequent-agreements-and-subsequent-practice/

UNCTAD (1996) The TRIPS agreement and developing countries. Available from https://unctad. org/en/docs/ite1_en.pdf

UNCTAD \& ICTSD (2005) Resource book on TRIPS and development. Cambridge University Press, Cambridge, p 467. Available from https://unctad.org/en/PublicationsLibrary/ ictsd2005d1_en.pdf

UNDP (2015a) The Doha Declaration 10 years on and its impact on access to medicines and the right to health. Available from https://www.undp.org/content/undp/en/home/librarypage/hivaids/doha10yearson.html

UNDP (2015b) Using competition law to promote access to medicine. Available from https://www. undp.org/content/undp/en/home/librarypage/hiv-aids/using-competition-law-to-promoteaccess-to-medicine.html

United Nations (2018) Report of the International Law Commission (A/73/10, 2018). Available from https://legal.un.org/ilc/reports/2018/english/a_73_10_advance.pdf 
United Nations General Assembly (2015) A/RES/70/1. Available from https://www.un.org/ga/ search/view_doc.asp?symbol=A/RES/70/1\&Lang $=\mathrm{E}$

Velásquez G, Correa CM, Ido V (2020) Intellectual property, human rights and access to medicines: a selected and annotated bibliography, 3rd edn. South Centre, Geneva. Available from https:// www.southcentre.int/book-by-the-south-centre-2020/\#more-14014

WHO, WIPO, and WTO (2012) Promoting access to medical technologies and innovation intersections between public health, intellectual property and trade. Available from https:// www.wipo.int/edocs/pubdocs/en/global_challenges/628/wipo_pub_628.pdf

WIPO (2010) Patent related flexibilities in the multilateral legal framework and their legislative implementation at the national and regional levels, p 11. Available from https://www.wipo.int/ meetings/en/doc_details.jsp?doc_id=142068

Open Access This chapter is licensed under the terms of the Creative Commons Attribution 4.0 International License (http://creativecommons.org/licenses/by/4.0/), which permits use, sharing, adaptation, distribution and reproduction in any medium or format, as long as you give appropriate credit to the original author(s) and the source, provide a link to the Creative Commons license and indicate if changes were made.

The images or other third party material in this chapter are included in the chapter's Creative Commons license, unless indicated otherwise in a credit line to the material. If material is not included in the chapter's Creative Commons license and your intended use is not permitted by statutory regulation or exceeds the permitted use, you will need to obtain permission directly from the copyright holder.

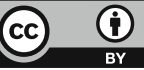

